\title{
Religijność uczniów szkół białostockich a stosunek do wybranych wartości, norm i zachowań
}

Eundamentem, na którym wznosi się porządek świata społecznego, jest aksjoF logia. Jak zauważa Jan Szymczyk, pełni ona wiele kluczowych zadań z punktu widzenia sprawnego funkcjonowania życia zbiorowego. Wśród nich wskazuje na wytwarzanie w jednostce określonych emocji ważących na przyjmowanych postawach. One „podpowiadają, jak z całej gamy dostępnych człowiekowi w doświadczeniu faktów jedne z nich identyfikować jako godne uznania i pożądania, inne jako niezasługujące na takie traktowanie, a nawet na ignorancję lub całkowite odrzucenie. Zinternalizowane wartości i normy stają się elementem struktury osobowości i w najróżniejszych sytuacjach nakierowują jednostki na konkretne cele oraz wskazują środki możliwe do ich realizacji; pełnią rolę ważnego motywatora i siły inspirującej do podejmowania konkretnych aktywności. Oczywiście nie determinują działań, a jedynie sytuują względem palety możliwości, która dostarcza wytycznych możliwych do wykorzystania w podejmowanych decyzjach $^{1}$. Socjolog podkreśla przy okazji omawiania tej funkcji, że jest ona podstawą wyodrębniania się stylów życia czy też mentalności poszczególnych grup

* Dr hab. Mariusz Zemło, prof. UwB - kierownik Zakładu Socjologii Wiedzy i Edukacji, Uniwersytet w Białymstoku, Instytut Socjologii, Uniwersytet w Białymstoku, e-mail: zemlo@uwb.edu.pl, ORCID: 0000-0003-0945-8651.

${ }^{1}$ J. Szymczyk, Wartości a zachowania i działania społeczne, w: Segmenty aktywności społecznej a wartości. Idee i praktyka, red. J. Szymczyk, Wydawnictwo KUL, Lublin 2012, s. 10-11, 16-17, 26; tenże, Zamiast wprowadzenia. O Katedrze Socjologii Makrostruktur i Ruchów Społecznych, w: Wartości - interesy - struktury społeczne. Uwarunkowania ludzkiej kreatywności i partycypacji w życiu publicznym, red. J. Szymczyk, Norbertinum, Lublin 2010, s. 6. 
społecznych. Aksjologia bowiem nie tylko decyduje o wyborach zasadniczych z punktu widzenia celów biograficznych (wartości ostateczne lub uroczyste), lecz także w sprawach najdrobniejszych, z którymi każda jednostka boryka się w swoich rutynowych czynnościach (wartości codzienne)². Oczywiście nieuniknionym następstwem spojrzenia przez ten aspekt na aksjologię jest pełnienie przez nią roli więziotwórczej. Jednostki o podobnym systemie wartości i akceptujące podobne normy zachowań odnajdują się w przestrzeni społecznej, z dużą łatwością wchodzą w ściślejsze interakcje ze sobą. Te z czasem się umacniają, doprowadzając do tworzenia zwartych społeczności czy zespołów. Ale nawet gdy nie dochodzi do pojawienia się więzi na tym poziomie, to i tak daje się mówić o orientacji aksjologicznej pewnych grup: wiekowych, zawodowych, politycznych, religijnych, narodowych itd. ${ }^{3} \mathrm{~W}$ prezentowanym materiale będziemy zmierzać do przedstawienia takiej orientacji charakteryzującej kilkunastoletnią młodzież.

Jak podkreśla Jan Szymczyk, perspektywa uwzględniająca aksjologię obowiązującą w badanej społeczności ,jest jednym z najbardziej istotnych podejść badawczych" w socjologii. Dostarcza bowiem wielu kluczowych informacji na temat życia społecznego, w tym struktury grup społecznych, tożsamości grupowych, mentalności zbiorowych, ruchów społecznych, stylów życia, nastrojów społecznych, działań grupowych itd. ${ }^{4}$ Całkowicie trzeba się z tym poglądem zgodzić. Zinternalizowane wartości i normy są bowiem rdzeniem konstrukcji osobowości poszczególnych jednostek społecznych, a także podstawową jakością charakteryzującą grupy społeczne. Stąd ich kondycja decyduje o wszystkich przejawach aktywności, zarówno konkretnej osoby, jak i zbiorowości. One bowiem wybudzają indywidualną oraz grupową czujność ze stanu uśpienia i dopominają się konkretnej odpowiedzi na płaszczyźnie emocji, namysłu i motoryki. To właśnie w owej odpowiedzi ucieleśnia się konkretny system aksjologiczny.

W prezentowanym tekście będziemy zmierzać do identyfikacji elementów systemu aksjologicznego (oczywiście w ograniczonym zakresie), jakie podzielają reprezentanci młodzieży szkolnej. Badaniom poddana została grupa podopiecznych szkół białostockich. W jej skład weszli uczniowie siódmej i ósmej klasy szkoły podstawowej oraz reprezentanci wszystkich klas szkół średnich, do matury włącznie. Badania przeprowadzono w grudniu 2019 r. Do obróbki statystycznej zaklasyfikowano 3752 ankiet. Udział uczniów poszczególnych placówek edukacyjnych był następujący: szkoła podstawowa 1014 osób (27\% próby), szkoła branżowa I stopnia - 203 osoby (5,4\% próby), technikum - 1207 osób (32,2\% próby), liceum ogólnokształcące - 1328 (35,4\% próby) ${ }^{5}$.

${ }^{2}$ Tenże, Wartości a zachowania i działania społeczne..., s. 17.

3 Tamże.

4 Tenże, Zamiast wprowadzenia..., s. 6-7.

${ }^{5}$ Badania były przygotowane i przeprowadzone przez Pracownię Badań, Analiz i Strategii Rozwoju Edukacji działającej przy Centrum Kształcenia Ustawicznego w Białymstoku. Autor tekstu w ramach 
Należy tutaj zaznaczyć fakt, podkreślany przez J. Szymczyka, że badanie preferowanych przez jednostki wartości i norm może dokonywać się w dwojaki sposób. Jeden z nich zmierza do wydobywania tych walorów ze sposobów myślenia o różnych społecznych sprawach (politycznych, gospodarczych, bezpieczeństwa, zdrowia, edukacji itd.) czy też z konkretnego zaangażowania się praktycznego w wybrane projekty, czy to o charakterze indywidualnym, czy zbiorowym. Ale można dochodzić do nich w drodze bezpośredniej - pytając się o rzeczy cenione przez badanych, o utożsamianie się z nimi respondentów ${ }^{6}$. $\mathrm{W}$ referowanym projekcie mamy do czynienia z tą drugą strategią.

W niniejszym opracowaniu zostanie zrekonstruowana hierarchia uznanych przez respondentów walorów w ujęciu ogólnym. Ten obraz zostanie nieco wzbogacony. Dla socjologa jest bowiem rzeczą oczywistą, że środowisko społeczne ma zasadnicze znaczenie w kształtowaniu kręgosłupa aksjologicznego jednostek. Na to środowisko składa się wiele elementów: rodzina i kultywowana $\mathrm{w}$ niej tradycja, rówieśnicy $\mathrm{z}$ odpowiednim nastawieniem do świata, media lansujące określone style życia, internet otwierający przed odbiorcami gąszcz, często przeciwstawnych walorów, szkoła transmitująca odpowiednio dobrane treści, obcowanie z różnymi formami kultury, grupy religijne, doświadczenia życiowe itd. Oczywiście trudno jest wskazać wpływ konkretnych czynników na formowanie się odpowiedniego systemu aksjologicznego, ale można poczynić korelacje, by uchwycić występujące związki między wybranymi elementem środowiska a wyszczególnionymi elementami tegoż systemu - co w ograniczonym zakresie będziemy starać się przedstawić, uwzględniając charakterystyczne dla badanego kontekstu zmienne niezależne.

Ponadto w prezentowanym opracowaniu zostanie skorelowana religijność młodzieży (tę potraktujemy jako zmienną niezależną) z wybranymi wartościami, normami społecznymi i zachowaniami (występującymi w dokonanym zestawieniu jako zmienne zależne). Oczywiście sama religijność jest wartością, ale może być postrzegana jako ekwiwalent przynależności do grupy religijnej; ekwiwalent przynależności do wspólnoty podzielającej jedną doktrynę (dogmaty, wyobrażenia tego, co święte i co profaniczne, przeznaczenie człowieka, normy etyczne), zachowania wyznaczane przez wskazania etyki kościelnej (uczestnictwo w praktykach religijnych) i wreszcie zachowania odnoszące się do

tego projektu był odpowiedzialny za kwestie omówione w niniejszym opracowaniu. Bliższe szczegóły dotyczące spraw metodologicznych znajdują się w raporcie Styl życia młodzieży Białegostoku, red. J. Mantur, Centrum Kształcenia Ustawicznego w Białymstoku, Białystok 2019, s. 6-10.

${ }^{6}$ J. Szymczyk, Instytucje, procesy i systemy społeczne. Makrosocjologia, w: 100 lat socjologii w Katolickim Uniwersytecie Lubelskim Jana Pawła II. Idee - Teorie - badania, red. W. Szymczak, TN KUL, Katolicki Uniwersytet Lubelkski Jana Pawła II, Lublin 2018, s. 82; tenże, Przemiany wartości i więzi we współczesnym społeczeństwie polskim, w: Odpowiedzialność społeczna w innowacyjnej gospodarce, red. P. Kowalec, A. Blachuta, Wydawnictwo KUL, Lublin 2011, s. 302. 
aktywności pozakościelnych realizujących się w obszarach działań prywatnych. W tym układzie zestawienie podstawowych wymiarów religijności z poglądami uczniów na wybrane elementy moralności może wiele powiedzieć na temat kondycji samej religii, co zakładamy, że nastąpi.

Przyjmujemy zatem zgodnie z dystynkcją stosowaną przez J. Szymczyka w badaniach nad wartościami „orientację na jednostkę”. Takie podejście socjo$\log$ zestawia $\mathrm{z}$ „orientacją na społeczeństwo”, kiedy analizowane są różne fakty społeczne przez pryzmat aksjologii ${ }^{7}$.

W pierwszej kolejności zostanie przedstawiona charakterystyka badanej grupy z punktu widzenia czynnika religijnego, a następnie przedłożone zestawienie elementów świadczących o stopniu identyfikacji z religią a opiniami młodzieży na temat wybranych elementów moralności.

\section{Religijność uczniów szkół białostockich}

Chcąc ująć religijność w perspektywie aksjologicznej, należy stwierdzić, że jest dobrem przynależącym do wartości ostatecznych w odróżnieniu od wartości codziennych. Skierowuje ona człowieka na rzeczywistość przekraczającą doczesność. Identyfikacja $\mathrm{z}$ nią decyduje o: przekonaniach, dokonywanych wyborach życiowych, obieraniu celów blisko- i dalekosiężnych, tożsamości, wewnętrznej integracji oraz wielu innych elementach pełniących kluczowe zadania w życiu człowieka ${ }^{8}$. W tradycji socjologicznej wypracowano zestaw wskaźników, za pomocą których można zidentyfikować ten społeczny fenomen. Zalicza się do nich: globalny stosunek do wiary, wiedzę religijną, ideologię religijną, praktyki religijne, wspólnotę religijną, moralność religijną. W niniejszym opracowaniu odwołamy się jedynie do dwóch z nich: autodeklaracji wiary oraz praktyk religijnych.

\section{Globalny stosunek do wiary}

Autoidentyfikacja religijna $\mathrm{z}$ reguły wiąże się z utożsamianiem się ze wspólnotą wierzących. Ten wskaźnik jedynie daje ogólną orientację o religijności badanych. Nie mówi wiele o więzi z Kościołem ani o przestrzeganiu etycznych wskazań wypływających z doktryny uznanej przez konfesję, z którą identyfikuje

7 Tenże, Instytucje, procesy i systemy społeczne..., s. 79; tenże, Katedra socjologii makrostruktur i ruchów społecznych, w: Tradycja i współczesność. 90 lat socjologii w Katolickim Uniwersytecie Lubelskim, red. S. Fel, J.P. Gałkowski, J. M. Zabielska, Wydawnictwo KUL, Lublin 2009, s. 147-150.

${ }_{8}$ Tenże, Wokót wartości i więzi społecznych Polaków. Wybrane aspekty i tendencje, „Zeszyty Naukowe KUL" 2010, t. 53, nr 4, s. 6. 
się informator, ale jedynie o woli bycia zaliczanym do społeczności uznających istnienie rzeczywistości pozaempirycznej ${ }^{9}$. Zatem w wielkim przybliżeniu daje sposobność zorientowania się w religijności badanych, dostarczając ogólnego, wstępnego i powierzchownego jej obrazu ${ }^{10}$. Wśród przebadanej młodzieży był następujący udział poszczególnych kategorii osób w różnym stopniu identyfikujących się z wiarą. „Głęboko wierzącymi” określiło się 10,8\% respondentów, „Wierzącymi” - 43,5\%, „niezdecydowanymi, ale przywiązanymi do tradycji” 19,3\%, „obojętnymi w sprawach religijnych” - 15,2\%, „niewierzącymi” - 11,2\%. Uzyskane wyniki pozwalają twierdzić, że ponad połowa uczniów silnie utożsamia się $\mathrm{z}$ wiarą, natomiast 1/3 respondentów (kategorie: „niezdecydowani, ale przywiązani do tradycji” oraz „obojętni w sprawach religijnych”) to potencjalni migranci z Kościoła, noszący w sobie możliwość przyłączenia się do grona niewierzących, czyli do grupy, dla której wiara pozostaje poza obszarem rzeczy ważnych ${ }^{11}$. W stosunku do edycji z 2011 r. przeprowadzonej także wśród uczniów szkół białostockich nastąpił nieznaczny spadek identyfikacji z wiarą. Wówczas wskazania na wyżej wyszczególnione kategorie wyrażały następujące wielkości $12,1 \%, 47,1 \%, 19,8 \%, 13,0 \%, 8 \%{ }^{12}$. W prowadzonych przez Janusza Mariańskiego badaniach wśród młodzieży szkół średnich z Puław uzyskano wyniki porównywalne do białostockich: głęboko wierzący - 7,5\%, wierzący $-46,4 \%$, niezdecydowani, ale przywiązani do tradycji - 23,3\%, obojętni w sprawach religijnych - 13,2\%, niewierzący - 8,8\%. Odsetek młodzieży deklarującej się jako głęboko wierzący w Białymstoku był nieco wyższy niż w Puławach, ale za to procent określających się jako niewierzący był wyższy ${ }^{13}$. W tym miejscu warto jeszcze przytoczyć dane Głównego Urzędu Statystycznego z 2018 r. informujące o globalnym stosunku do wiary Polaków w wieku 16+. Według tego źródła określało się jako głęboko wierzących 11,1\%, jako wierzących - 69,6\%, jako niezdecydowanych lub poszukujących - 10,7\%, jako obojętnych - 5,6\%, jako niewierzących - 3,0\%. Na tle tego zestawienia religijność uczniów szkół białostockich, w omawianym wymiarze, wypada zdecydowanie słabiej. Świadczą o tym wszystkie wyszczególnione kategorie odpowiedzi. Trzeba jednak pamiętać, że dane ogólnopolskie odnoszą się także do pokolenia dorosłych, wśród których identyfikacja z religią z reguły jest silniejsza niż wśród młodzieży ${ }^{14}$.

9 J. Mariański, Maturzyści puławscy w latach 1994-2016. Szkic do portretu młodych Polaków, Warszawskie Wydawnictwo Socjologiczne, Warszawa 2019, s. 36-37.

10 Tenże, Religijnosocjologiczne wyzwania dla pedagogiki religii. Studium socjologiczne, Wydawnictwo Adam Marszałek, Toruń 2021, s. 184-185.

11 Tamże, s. 200.

12 Tenże, Między szkoła a domem. Konteksty socjalizacyjne młodzieży szkół ponadpodstawowych, Wydawnictwo KUL, Lublin 2013, s. 294.

13 Tenże, Maturzyści puławscy w latach 1994-2016..., s. 38.

14 Jakość życia i kapitał społeczny w Polsce. Wyniki badań spójności społecznej 2018, GUS, Warszawa 2020, s. 111-112. 


\section{Płeć a stosunek do wiary}

We wszystkich badaniach potwierdza się fakt, że kobiety bardziej identyfikują się z wiarą niż mężczyźni ${ }^{15}$. W referowanym przypadku mamy do czynienia z podobną sytuacją. Świadczą o tym wskazania na kategorie silnie identyfikujące z wiarą, jak i kategorie mówiące o słabej identyfikacji. Głosy młodzieży na wyszczególnione tożsamościowe identyfikacje z wiarą rozkładały się w sposób następujący w przypadku reprezentantów obu płci. Kobiety: głęboko wierzące $-11,1 \%$, wierzące - 45,5\%, niezdecydowane, ale przywiązane do tradycji religijnej - 21,1\%, obojętne w sprawach religijnych $-13,0 \%$, niewierzące $-9,3 \%$. Mężczyźni: głęboko wierzący - 10,6\%, wierzący - 41,5\%, niezdecydowani, ale przywiązani do tradycji religijnej - 17,4\%, obojętni w sprawach religijnych $17,3 \%$, niewierzący $-13,2 \%$.

\section{Rodzaj szkoły a stosunek do wiary}

Zazwyczaj przynależność do odpowiedniego typu placówki edukacyjnej różnicuje stosunek do wiary. Jak było w referowanym przypadku, pokażą wyniki. Uczniowie szkoły podstawowej w następujący sposób identyfikowali się wiarą: głęboko wierzący - 12,0\%, wierzący - 49,7\%, niezdecydowani, ale przywiązani do tradycji religijnej - 17,8\%, obojętni w sprawach religijnych 11,9\%, niewierzący - 8,6\%. Uczniowie szkoły branżowej odnieśli się natomiast do tej samej kwestii w proporcjach: głęboko wierzący - 7,4\%, wierzący - 39,9\%, niezdecydowani, ale przywiązani do tradycji religijnej - 20,2\%, obojętni w sprawach religijnych - 19,2\%, niewierzący - 13,3\%. U młodzieży z technikum zanotowano odpowiednio następujące wskazania na wyszczególnione kategorie: $8,1 \%, 43,4 \%, 18,6 \%, 18,0 \%, 11,9 \%$. Licealiści swój stosunek do wiary wyrażali zgodnie z poniższym zestawieniem: 12,9\%, 39,4\%, 20,9\%, 14,5\%, 12,3\%. Biorąc pod uwagę odpowiedzi silnie identyfikujące $z$ wiarą i wskazujące na słabe lub brak jakichkolwiek relacji względem uznania rzeczywistości pozaempirycznej, religijność w omawianym aspekcie układa się w sposób następujący, uwzględniając kierunek słabnięcia związków: uczniowie szkoły podstawowej, licealiści, przyszli technicy, uczniowie szkół branżowych. Można zatem powiedzieć, że

${ }^{15}$ J. Mariański, Maturzyści puławscy w latach 1994-2016..., s. 38, 40-41; tenże, Religijnosocjologiczne wyzwania dla pedagogiki religii..., s. 190-197; M. Zemło, Między szkoła a domem..., s. 295; S.H. Zaręba, Socjologiczne interpretacje moralnych poglądów i ocen polskiej młodzieży szkolnej i akademickiej, w: Wartości postawy i więzi moralne w zmieniającym się społeczeństwie, red. J. Mariański, L. Smyczek, Wydawnictwo WAM, Polskie Towarzystwo Socjologiczne, Kraków 2008, s. 208; J. Mariański, Kondycja religijna i moralna młodzieży szkół średnich w latach 1988-1998-2005-2017 (raport z ogólnopolskich badań socjologicznych), Wydawnictwo Adam Marszałek, Toruń 2018, s. 106, 108. 
najmłodsi oraz reprezentanci placówek o profilu ogólnokształcącym górują nad uczniami szkół sprofilowanych w omawianej kwestii.

\section{Średnia z ocen a stosunek do wiary}

Średnia z ocen, jaką zdobywali uczniowie w roku poprzedzającym badania, była kolejną zmienną niezależną korelowaną ze stosunkiem do wiary. W tym przypadku uzyskano następujące zestawy wyników. Wśród uczniów jedynkowych (średnia poniżej 2) głosy rozkładały się w sposób jak niżej: głęboko wierzący - 24,0\%, wierzący - 24,0\%, niezdecydowani, ale przywiązani do tradycji religijnej - 8,0\%, obojętni w sprawach religijnych - 12,0\%, niewierzący - 32,0\%. Wśród dwójkowych (średnia od 2,1 do 3) wskazania były odpowiednie: 8,2\%, $33,6 \%, 17,7 \%, 24,2 \%, 16,3 \%$; wśród uczniów trójkowych (średnia od 3,1 do 4): $6,7 \%, 44,0 \%, 19,0 \%, 18,4 \%, 11,9 \%$; w grupie czwórkowych (średnia od 4,1 do 5): $10,5 \%, 46,7 \%, 21,1 \%, 12,3 \%, 9,5 \%$; w grupie piątkowych (średnia powyżej 5): $18,5 \%, 44,1 \%, 18,2 \%, 10,1 \%, 9,1 \%$.

Procentowo najwięcej uczniów deklarujących się jako głęboko wierzący wystąpiło w grupie zdobywających najsłabsze wyniki (było ich o 6,5\% więcej niż w grupie młodzieży piątkowej), ale w tej samej grupie był także największy odsetek identyfikujących się jako niewierzący (tych było pond trzykrotnie więcej niż w grupie uczniów zdobywających najlepsze wyniki). Biorąc jednak pod uwagę wszystkie kategorie, zauważamy jednoznaczną tendencję, zgodnie z którą wraz ze wzrostem średniej z ocen rośnie identyfikacja respondentów z wiarą.

\section{Ocena sytuacji materialnej a stosunek do wiary}

Kolejną zmienną niezależną korelowaną ze stosunkiem do wiary była ocena kondycji materialnej rodzin młodzieży biorącej udział $\mathrm{w}$ badaniach. W tym przypadku wyniki rozłożyły się zgodnie z prezentowanym porządkiem, w przypadku każdej z wyszczególnionych grup. Oceniający sytuację rodziny jako bardzo dobrą: głęboko wierzący - 14,1\%, wierzący - 46,7\%, niezdecydowani, ale przywiązani do tradycji religijnej - 16,0\%, obojętni w sprawach religijnych - 12,6\%, niewierzący - 10,7\%; wśród oceniających sytuację materialną jako dobrą zanotowano następujący rozkład wyników: 8,7\%, 46,0\%, 19,9\%, 14,5\%, 11,0\%; jako średnią: $10,2 \%, 35,1 \%, 23,5 \%, 19,3 \%, 11,9 \%$, jako raczej złą: $13,6 \%, 25,0 \%, 18,2 \%, 27,3 \%, 15,9 \%$; jako bardzo złą: 37,5\%, 20,8\%, 4,2\%, 16,7\%, 20,8\%. Gdyby pominąć odpowiedzi uczniów najsłabiej oceniających sytuację materialną swojej rodziny, to otrzymalibyśmy jednoznaczną tendencję świadczącą, że wraz ze spadkiem oceny kondycji materialnej spada odsetek uczniów 
identyfikujących się z wiarą. Jednak wysoki odsetek (najwyższy ze wszystkich grup) określających się jako głęboko wierzący, występujący w grupie najsłabiej oceniających sytuację materialną, zakłócił taką tendencję i uplasował tę grupę zaraz po „dobrze” oceniających uposażenie materialne swojej rodziny, czyli w środku wyszczególnionych kategorii.

\section{Praktyki religijne a stosunek do wiary}

Zdrowy rozsądek podpowiada, że praktyki religijne powinny iść w parze ze stopniem utożsamiania się z wiarą. To znaczy, gdy ich częstotliwość się zwiększa, to silniejsza winna być owa identyfikacja. Takie przypuszczenie potwierdzają wszystkie grupy, które były wyszczególnione w badaniu. Rozkład wyników przedstawiono $\mathrm{w}$ poniższym zestawienieniu. Praktykujący raz w tygodniu i częściej: głęboko wierzący - 22,5\%, wierzący - 58,5\%, niezdecydowani, ale przywiązani do tradycji religijnej - $12,8 \%$, obojętni w sprawach religijnych $3,8 \%$, niewierzący $-2,4 \%$; praktykujący od 1 do 3 razy w miesiącu: $5,3 \%, 57,2 \%$, $26,2 \%, 8,8 \%, 2,6 \%$; praktykujący kilka razy w roku: 1,9\%,33,3\%, 34,3\%, 25,1\%, $5,4 \%$, niepraktykujący: $1,8 \%, 12,4 \%, 10,6 \%, 33,1 \%, 42,0 \%$.

\section{Praktyki religijne}

Drugim najczęściej badanym przez socjologów aspektem religijności są praktyki religijne. One zdecydowanie wychodzą już poza wymiar deklaratywnego przywiązania do wiary. Tu już sięgamy do konkretnych zachowań świadczących o tym, że mówienie o sobie jako osobie religijnej ma jednoznaczne oparcie w empirii. Dopiero w praktyce wiara staje się żywa. Autodeklaracja wiary bez zaangażowania w najróżniejsze formy kultu wzmacniające więzi z sacrum staje się jedynie martwym wyznaniem jakiegoś przyporządkowania lub rodzajem światopoglądu, tudzież ideologii ${ }^{16}$. Przez uczestnictwo w aktywnościach o charakterze rytualno-kultowym dajemy wyraz przekonaniu o słuszności wyboru konfesji, $\mathrm{z}$ którą się utożsamiamy ${ }^{17}$. Z punktu widzenia socjologa zaangażowanie $\mathrm{w}$ ten wymiar religijności jest najbardziej ewidentnym i jednoznacznym wskaźnikiem przynależności do Kościoła ${ }^{18}$. Ponadto należy pamiętać, że identyfikacja z wiarą lub jej brak może być dokonana koniunkturalnie. Jeśli korzyści podpowiadają, że lepiej ogłosić się wierzącym - to taką tożsamość sobie przypisujemy, jeśli

\footnotetext{
${ }_{16}$ J. Mariański, Maturzyści puławscy w latach 1994-2016..., s. 43.

17 Tenże, Religijnosocjologiczne wyzwania dla pedagogiki religii..., s. 238

18 Tamże, s. 241-242.
} 
w innych okolicznościach lepiej okazać się niewierzącym - wówczas takim się określamy. Udział w praktykach jest tutaj bardziej wiarygodnym miernikiem życia wartościami związanymi z transcendencją niż autodeklaracja wiary. On mówi, co się kryje za konkretną deklaracją. Dodajmy, że w polskich warunkach praktyki religijne utożsamia się głównie z udziałem w niedzielnej mszy św.

Biorąc pod uwagę czynnik zaangażowania badanych uczniów w praktyki religijne, otrzymaliśmy następujący rozkład wyników. Deklarację udziału w takich praktykach raz w tygodniu i częściej głosi 40,4\% respondentów, „od 1 do 3 razy w miesiącu” taki udział zgłasza 18,2\%, „kilka razy w roku” - 20,8\%, do braku udziału w praktykach religijnych przyznaje się 20,6\%. Dla porównania warto tutaj przytoczyć wyniki uzyskane w badaniach białostockich w $2011 \mathrm{r}$. Wówczas wskazania na wyżej wyszczególnione kategorie kształtowały się następująco: $37,4 \%, 25,3 \%, 22,8 \%, 14,5 \%$. Wyraźnie widać, że nawet na przestrzeni kilku lat zdecydowanie osłabł udział uczniów w praktykach religijnych ${ }^{19}$. Dla uzyskania porównania stanu omawianego zjawiska na Podlasiu z kontekstem ogólnopolskim przytoczmy wyniki ekspertyz CBOS z 2018 r. Z nich wynika, że przynajmniej raz w tygodniu w praktykach uczestniczy $35 \%$ badanych, jeden lub dwa razy w miesiącu - 11\%, kilka razy w roku - 18\%, nie uczestniczy $\mathrm{w}$ ogóle $-35 \%{ }^{20}$. Niech to zestawienie wzmocnią jeszcze dane odnoszące się do praktyk religijnych, w które są zaangażowane jednostki mające szesnaście lat i starsze, przedstawione przez Główny Urząd Statystyczny w Warszawie. Prezentowane wyniki odnoszą się do stanu z 2018 r. i wyrażają się w następującym zestawieniu: praktykuje codziennie lub częściej - 3,5\%, raz w tygodniu 46,5\%, jeden lub dwa razy w miesiącu - 17,3\%, z okazji większych świąt lub rzadziej $26,4 \%$, nigdy $-6,3 \%{ }^{21}$. Porównując zaprezentowane rezultaty badań, widzimy, że w wymiarze praktyk religijnych młodzież białostocka wypada zdecydowanie lepiej w porównaniu z ogólnopolską próbą młodzieży (decyduje o tym kategoria wskazująca na brak uczestnictwa w rytuałach), jednak w zestawieniu z próbą nieograniczającą się do młodzieży wykazuje się mniejszym zaangażowaniem w praktyki religijne.

Wracając do danych białostockich, zauważamy, że praktyki religijne młodzieży nieco odbiegają od deklarowanych identyfikacji z religią (wykazują się mniejszą intensywnością), a ponadto spada w nich udział uczniów w kolejnych badaniach $^{22}$. J. Szymczyk taki stan rzeczy tłumaczy faktem, że sytuacji pluralizmu,

${ }^{19}$ M. Zemło, Między szkoła a domem..., s. 306.

20 J. Mariański, Maturzyści puławscy w latach 1994-2016..., s. 45.

${ }^{21}$ Jakość życia i kapitał społeczny w Polsce..., s. 115-117.

22 Zanotowaną zależność potwierdzają także inne badania: S.H. Zaręba, Socjologiczne interpretacje moralnych poglądów..., s. 231; J. Mariański, Kondycja religijna i moralna młodzieży szkót średnich w latach 1988-1998-2005-2017..., s. 134-192; tenże, Religijnosocjologiczne wyzwania dla pedagogiki religii, s. 237-288. 
jaką obserwujemy przez ostatnie dziesięciolecia w Polsce, sprawia, że pojawiają się formy religijności pozainstytucjonalnej. Członkowie społeczeństwa stojącego w obliczu urynkowienia religii w autorski sposób konstruują jej postać, z którą chcieliby się utożsamiać. $Z$ jednej strony ze znanego sobie systemu religijnego odrzucają to, co im nie jest wygodne, z czym się nie zgadzają, to, co budzi ich niechęć, a z drugiej - zapożyczają ze znanych sobie systemów religijnych wybrane elementy i włączają w zakres przez siebie konstruowanego modelu. Następstwem takiego działania jest m.in. podchodzenie do wybranych praktyk religijnych w sposób wybiórczy lub też całkowite ich odrzucenie. Jak zauważa socjolog, szczególnie dotyczy to dużych miast i młodego pokolenia. Podkreśla ponadto, że zanotowany trend wpisuje się w scenariusze religijności realizowane w krajach Europy Zachodniej ${ }^{23}$. Z takiego ujęcia sprawy można wnosić, że J. Szymczyk przewiduje, że mimo odmiennego kontekstu doświadczeń historycznych, innego umocowania religii w społeczności wiernych, szczególnego rysu religijności polskiej wejdziemy na ścieżkę przemian, jaka została już przetarta w krajach, u których zauważa się poważny kryzys religijności instytucjonalnej. Byłoby to realizowanie scenariusza przemian religijności w wariancie pesymistycznym - jak to określa J. Mariański w jednej ze swoich ostatnich książek. W tym scenariuszu jednostki konstruując swoje modele życia religijnego, przyczyniają się do powstawania nowej jakości w omawianym obszarze $\mathrm{w}$ porównaniu z tradycyjną religijnością. Mamy wówczas do czynienia z powstawaniem czegoś na kształt: alternatywnej religijności, duchowości niereligijnej, religijności niekonsekwentnej, religijności zdesakralizowanej. Efektem tego społeczny wymiar wiary staje się wielopłaszczyznowy i różnorodny. Przestrzeń takich konstruktów przestaje być przestrzenią jednoznacznych rozgraniczeń między religijnością a agnostycyzmem lub ateizmem. Granice między sacrum i profanum zaczynają się rozmywać ${ }^{24}$.

\section{Płeć a częstotliwość praktyk religijnych}

Kobiety częściej niż mężczyźni wykazują się uczestnictwem w praktykach religijnych. Badania ogólnopolskie, jak i lokalne dowodzą, że różnica między reprezentantami obu płci, w omawianym względzie, wynosi od kilku do kilkuna-

${ }^{23}$ J. Szymczyk, Wartości a zachowania i działania społeczne..., s. 24-25; tenże, Wokół wartości i więzi społecznych Polaków..., s. 14.

${ }^{24}$ J. Mariański, Scenariusze przemian religijności i Kościoła katolickiego w społeczeństwie polskim. Studium diagnostyczno-prognostyczne, Wyższa Szkoła Nauk Społecznych z siedzibą w Lublinie, Lublin 2021, s. $21 \mathrm{n}$. 
stu punktów procentowych ${ }^{25}$. Taka zależność potwierdziła się także i badaniach białostockich. Choć w omawianym przypadku nie było zdecydowanej różnicy między płciami, niemniej daje się dostrzec większą obecność praktyk w życiu duchowym reprezentantów płci żeńskiej. Udział w praktykach raz w tygodniu lub częściej deklaruje 41,8\% uczennic, od 1 do 3 razy w miesiącu -19,9\%, kilka razy w roku 20,9\%, nie praktykuje 17,5\%. Wśród mężczyzn odpowiedzi odnoszące się do tych samych częstotliwości układały się następująco: 39,0\%, 16,6\%, $20,8 \%, 23,7 \%$. Największe dysproporcje między reprezentantami badanych grup wystąpiły przy kategorii „nie praktykuję”. To właściwie ta kategoria zdecydowanie przypieczętowała wspomnianą zależność, chociaż także w grupie najbardziej zaangażowanych w praktyki kobiet było o blisko 3\% więcej niż chłopców.

\section{Rodzaj szkoły a częstotliwość praktyk religijnych}

Uczniowie szkoły podstawowej zdecydowanie najczęściej deklarują kontakty z praktykami religijnymi. Do praktykowania raz w tygodniu lub częściej przyznaje się 47,9\% uczniów, od 1 do 3 razy w miesiącu - 23,1\%, kilka razy w roku $16,5 \%$, ignoruje praktyki $12,5 \%$. Na kolejnym miejscu uplasowali się uczniowie liceum ogólnokształcącego z następującymi wskazaniami: 42,5\%,16,0\%, 20,5\%, $21,1 \%$. W prezentowanym zestawieniu reprezentanci szkół technicznych znaleźli się na trzecim miejscu, głównie dzięki wyraźnie niższemu zaangażowaniu w praktyki o największej częstotliwości oraz nieco większemu, niż licealiści, odsetkowi niepraktykujących. Cały zestaw wyników przybrał następująca postać 34,4\%, 17,1\%, 23,6\%, 24,9\%. Zdecydowanie najrzadziej praktykują uczniowie szkół branżowych. Wśród nich jest radykalnie najniższy procent praktykujących z najwyższą częstotliwością - ponad dwukrotnie mniejszy niż wśród uczniów najmłodszych oraz zdecydowanie największy odsetek niepraktykujący 2,5 raza większy niż u uczniów szkół podstawowych. Zestaw wyników uzyskanych przez reprezentantów tego rodzaju szkół jest następujący: 24,1\%, 15,8\%, 28,1\%, 32,0\%.

Nasuwają się tutaj podobne wnioski jak w przypadku autodeklaracji wiary. Najmłodsi wiekiem oraz reprezentanci szkół ogólnokształcących częściej praktykują niż uczniowie szkół sprofilowanych. A w tej ostatniej grupie najrzadziej praktykują osoby uczęszczające do placówek o najniższych wymogach edukacyjnych.

${ }_{25}$ Tenże, Maturzyści puławscy w latach 1994-2016..., s. 46; tenże, Religijnosocjologiczne wyzwania dla pedagogiki religii..., s. 245, 247-249, 252; tenże, Kondycja religijna i moralna młodzieży szkót średnich w latach 1988-1998-2005-2017..., s. 143-145, 154, 159. 
Średnia ocena zdobyta przez uczniów na koniec roku poprzedzajacego badania a częstotliwość praktyk religijnych

Największe zaangażowanie w praktyki religijne deklarują uczniowie osiągający najwyższe średnie z ocen, czyli powyżej 5,0. W następujący sposób wyrażają swój udział w praktykach religijnych: praktykowanie raz w tygodniu lub częściej deklaruje 53,7\% uczniów, od 1 do 3 razy w miesiącu - 17,0\%, kilka razy w roku $16,1 \%$, nie praktykuje $13,2 \%$. Na kolejnym miejscu uplasowali się uczniowie uzyskujący średnią od 4,1 do 5,0. Rozkład ich wyników ułożył się odpowiednio: 44,5\%, 20,1\%, 19,6\%, 15,8\%. Dalej znaleźli się uczniowie, których średnia $\mathrm{z}$ ocen mieściła się $\mathrm{w}$ przedziale od $3,1 \%$ do 4,0 . Ich odpowiedzi rozłożyły się następująco: 34,1\%, 17,7\%, 24,7\%, 13,6\%. Od trójkowych uczniów słabszą intensywnością praktyk wykazali się uczniowie dwójkowi (średnia od $2,1$ do $3,0 \%)$. Ich udział w praktykach to: $22,6 \%, 17,9 \%, 22,8 \%, 36,6 \%$. Zdecydowanie najrzadziej praktykują przedstawiciele uczniów, których średnia nie przekraczała 2,0. W tym przypadku ciąg wyników przybrał następującą postać: $30,0 \%, 6,0 \%, 14,0 \%, 50,0 \%$.

Uzyskany materiał pozwala na jednoznaczne stwierdzenie, że wraz z obniżaniem się średniej uzyskiwanej przez uczniów słabnie ich udział w praktykach. Jeśli połączymy dwie kategorie świadczące o najczęstszym uczestnictwie w praktykach, to między piątkowymi i jedynkowymi uczniami pojawi się niemal $35 \%$ przepaść $(70,7 \%$ do $36,0 \%$ ), podobnie jeśli porównamy osoby w ogóle niepraktykujące z tych skrajnych grup. W tym przypadku biegunowo oddalone od siebie wielkości dzieli dystans ponad 36\% (13,2\% do 50,0\%). Można powiedzieć, że mamy tutaj do czynienia $\mathrm{z}$ zupełnie odmiennymi światami życia religią.

\section{Ocena sytuacji materialnej rodziny a częstotliwość praktyk religijnych}

Zgodnie z uzyskanymi odpowiedziami uczniów szkół białostockich największe zaangażowane $\mathrm{w}$ praktyki religijne można przypisać oceniającym sytuację materialną swojej rodziny jako „bardzo dobra”. Wśród tej grupy blisko połowa przyznaje się do praktyk raz w tygodniu i częściej (46,6\%), od 1 do 3 razy w miesiącu $-18,1 \%$, kilka razy w roku 17,4\%, nie praktykuje $18,0 \%$. Niewiele słabszy udział w praktykach zanotowano u młodzieży określającej sytuację materialną jako „raczej dobra”. W tej grupie wyniki kształtują się następująco: $40,6 \%, 18,7 \%, 20,6 \%, 20,1 \%$. Na kolejnym miejscu znaleźli się uczniowie określający sytuację swojej rodziny jako „bardzo złą”. Wśród nich deklarujących praktyki religijne jako „raz w tygodniu lub częściej” było 41,7\%, zatem nieco więcej niż w poprzedniej grupie, ale pozostałe wielkości były już zdecydowanie słabsze, a szczególnie wskazania na kategorię „nie praktyku- 
ję”. Ostatecznie zanotowano następujące wielkości: 12,5\%, 16,7\%, 29,2\%. Na kolejnych miejscach znaleźli się uczniowie określający swoją sytuację materialną jako „średnią" $\mathrm{z}$ wynikami: 31,7\%, 17,6\%, 26,6\%, 24,1\%, oraz „raczej złą" - 26,1\%, 15,9\%, 23,9\%, 34,1\%. Gdyby nie wyniki grupy respondentów najsłabiej oceniających sytuację ekonomiczną swoich rodzin, szczególnie stosunkowo wysoki wynik wskazań (wśród reprezentantów tej grupy) na kategorię określającą największą częstotliwość takich praktyk, mielibyśmy do czynienia z sytuacją świadczącą, że im wyżej jest oceniany przez respondentów stan ekonomiczny ich rodzin, tym zwiększa się częstotliwość uczestnictwa w praktykach religijnych.

Takie wynik mogą być zaskoczeniem w kontekście teorii głoszących, że wraz z podnoszeniem się dobrobytu słabnie religijność. Może ta zależność obowiązuje w przypadku stosunkowo wysokiego poziomu dobrostanu, natomiast badana młodzież jeszcze nie funkcjonuje na poziomie, by dobra materialne mogły jej przysłonić wartości transcendentne przynależące do wymiaru idealnego.

\section{Stosunek do wiary a deklarowany udział w praktykach religijnych}

Zdrowy rozsądek podsuwa występowanie zależności świadczącej, że im bardziej zwiększa się przywiązanie jednostek do wiary, tym częstszy powienien być ich udział w praktykach religijnych. Istnienie takiej zależności jednoznacznie potwierdzają uzyskane w referowanych badaniach wyniki. W poszczególnych grupach uczniów odpowiednio identyfikujących się z wiarą zanotowano niżej przytoczone dane. „Głęboko wierzący/wierząca”: raz w tygodniu i częściej $84,0 \%$, od 1 do 3 razy w miesiącu $-8,9 \%$, kilka razy w roku 3,7\%, nie praktykuje 3,4\%; „wierzący/wierząca”: 54,2\%, 24,0\%, 15,9\%, 5,9\%; „niezdecydowany/ niezdecydowana, ale przywiązany/przywiązana do tradycji": 26,8\%, 24,8\%, 37,1\%, 11,3\%; „obojętni w sprawach religijnych”: 10,0\%, 10,5\%, 34,4\%, 45,0\%. Listę zamykają „niewierzący”: 8,8\%, 4,3\%, 10,0\%, 77,0\%.

$$
* * *
$$

W podsumowaniu uzyskanych efektów badań należy wskazać najbardziej wyraziste związki występujące między zmiennymi niezależnymi a religijnością. Powiązania te są aktualne dla obu wymiarów religijności: autodeklaracji wiary oraz praktyk religijnych.

- Kobiety wykazują się większą religijnością niż mężczyźni.

- Uczniowie szkół podstawowych i ogólnokształcących wykazują się większą religijnością niż młodzież z placówek sprofilowanych. Zdecydowanie 
najsłabsza jest religijność młodzieży uczęszczającej do szkół branżowych (o najniższych wymogach edukacyjnych).

- Im wyższa średnia z uzyskiwanych ocen, tym większą notuje się religijność młodzieży.

- Zauważa się także prawidłowość (którą zakłócają reprezentanci określający siebie jako najniżej sytuowanych materialnie), że im lepsza kondycja materialna, tym większa religijność. Wyszczególniona grupa ze swoją religijnością plasuje się w środku zestawienia.

\section{Religijność a stosunek do wybranych wartości}

Za wartości przyjmuje się w socjologii dobra, które są uznane za ważne, godne zabiegania, otaczania szacunkiem, zdobycia. W takim ujęciu wartościami mogą być „dowolne przedmioty materialne lub idealne, idee lub instytucje, przedmioty rzeczywiste lub wyimaginowane"26. W socjologii prowadzono bogaty namysł nad wartościami. Jego efektem są m.in. typologie wartości. Warto tutaj wspomnieć o kilku z nich, choćby odwołując się jedynie do dorobku polskich uczonych: wartości uznawane i odczuwane, wartości środki i wartości cele, uroczyste i codzienne (Stanisław Ossowski); wartości osobowe i społeczne (J. Mariański); psychologiczne, socjologiczne, kulturowe (Maria Misztal). $\mathrm{W}$ refleksji nad wartościami prowadzi się także dyskusję nad ich statusem ontologicznym. W tym momencie będzie stosowne odwołanie się do ujęcia tej kwestii przez J. Szymczyka. Należy stwierdzić, że nie odnajdujemy u tegoż autora jednoznacznego spojrzenia w podjętej sprawie. Na czoło wysuwają się dwa różne poglądy. Jeden z nich obecny był we wstępnej refleksji uczonego nad tym zagadnieniem i łączył się ze stanowiskiem, które można nazwać obiektywizmem aksjologicznym. Zakładał on bowiem istnienie wartości w sposób niezależny od człowieka. Jednostka ma je odszukać, rozpoznać i uznać za ważne, godne zabiegania. W tym ujęciu są one odkrywane w najróżniejszych kontekstach działań człowieka. Nie podlegają one, jak zauważa socjolog, „wypaczeniom, fluktuacjom", a zatem mają autonomiczność ontologiczną ${ }^{27}$. Choć - jak zauważa lubelski badacz - mogą być nieobecne w świecie ludzkich działań. Dopiero gdy stają się obiektem troski, odniesienia artystycznego, refleksji, dyskusji, pobudzenia do reakcji, ożywiają się; stają się czynnym elementem życia społecznego. W tym ujęciu pozostaje pod wpływem poglądów Władysława Stróżewskiego ${ }^{28}$.

${ }^{26}$ J. Szczepański, Elementarne pojęcia socjologii, PWN, Warszawa 1970, s. 97; J. Szymczyk, Wartości a zachowania i działania społeczne..., s. 10.

27 J. Szymczyk, Odkrywanie wartości. Z problematyki socjologiczno-aksjologicznej, Polihymnia, Lublin 2004, s. 8; tenże, Wokół wartości i więzi społecznych Polaków..., s. 5, 7-8.

28 Tenże, Odkrywanie wartości..., s. 254. 
Zauważamy również odmienne ujęcie tej kwestii w pismach J. Szymczyka. Te można nazwać relacyjnym. Z tym mamy do czynienia w sytuacji, gdy wartość konstytuuje się $\mathrm{w}$ zestawieniu bytu osobowego $\mathrm{z}$ przedmiotem podlegającym ocenie. To w konfrontacji z określonym obiektem dokonuje się jego waloryzacja - uznanie za ważny lub nieważny, istotny lub nieistotny, szlachetny lub nieszlachetny itd. Jednoznacznie z takim ujęciem spotykamy się w stwierdzeniu „Wartość jest bowiem wynikiem relacji doznającego i aktywnego podmiotu wobec pewnych przedmiotów zewnętrznego świata". J. Szymczyk w późniejszych swoich pracach pisze, że jest to „najbardziej właściwe podejście do badania świata wartości”29.

W referowanych badaniach młodzieży został podany zestaw 19 wartości, spośród których miała wybrać 3 najbardziej przez sobie cenione. Zestawiając uzyskane dane, otrzymaliśmy następującą hierarchię najbardziej darzonych względami przez respondentów dóbr: szczęśliwe życie rodzinne (56,9\%), zdrowie (55,2\%), spokojne życie (38,6\%), pieniądze/zamożność (37,5\%), odwzajemniona miłość $(37,2 \%)$, prawdziwi przyjaciele $(36,2 \%)$, kariera zawodowa $(27,9 \%)$, podróże/przygoda $(27,8 \%)$, interesująca praca $(27,0 \%)$, wiara/religia $(18,1 \%)$, szacunek i uznanie innych ludzi (17,8\%), silny charakter (13,7\%), przyjemności i rozrywki (11,9\%), pomaganie innym ludziom (11,3\%), poczucie, że jest się potrzebnym innym ludziom $(10,6 \%)$, sprawność fizyczna $(10,3 \%)$, zdobywanie wiedzy $(8,6 \%)$, sława $(5,7 \%)$, dobro ojczyzny $(4,8 \%)^{30}$.

Nie wnikając w specyfikę dokonanych przez respondentów wyborów, zestawmy je $\mathrm{z}$ dwoma wymiarami religijności, które zostały zidentyfikowane u uczestników badań. By uniknąć przywoływania wszystkich uzyskanych wyników, ograniczymy się jedynie do przytoczenia danych, w przypadku których dało się dostrzec jednoznaczne prawidłowości. Pozwoli to na uniknięcie niepotrzebnego mnożenia statystyk, a jedynie zacytowania wyników, które pozwalają wyciągać czytelne wnioski.

\section{Pieniądze i zamożność}

W referowanych badaniach notujemy jednoznaczną zależność: wraz ze słabnięciem identyfikacji z wiarą zwiększa się odsetek uczniów ceniących wskazaną wartość. Dobitnie pokazuje to następujący ciąg wielkości: głęboko wierzący $25,8 \%$, wierzący $-31,8 \%$, niezdecydowani w sprawach wiary, ale przywiązani do tradycji - 38,3\%, obojętni w sprawach religijnych - 49,9\%, niewierzący - 53,6\%.

${ }^{29}$ Tenże, Instytucje, procesy i systemy społeczne..., s. 78.

${ }^{30}$ Uzyskana hierarchia wartości bliska jest zestawieniu dokonanemu przez J. Szymczyka (tenże, Wartości a zachowania i działania społeczne..., s. 23). 
Skrajne stanowiska dzieli przedział 27,8\%. W przypadku praktyk religijnych była utrzymana podobna tendencja: zmniejszenie się udziału młodzieży w praktykach jednoznacznie łączył się ze zwiększaniem odsetka wskazań na pieniądze i zamożność. Praktykujący raz w tygodniu i częściej - 32,2\%, od 1 do 3 razy w miesiącu - 35,0\%, kilka razy w roku 37,3\%, niepraktykujący $-50,7 \%$. W tym przypadku skrajne stanowiska dzielił przedział $18,5 \%$.

\section{Przyjemność i rozrywka}

Zestawiając „przyjemność i rozrywkę" z wyszczególnionymi parametrami religijności, także obserwuje się niezakłóconą zależności. Wraz ze słabnięciem identyfikacji z wiarą wzrasta odsetek uczniów ceniących „przyjemność i rozrywkę": głęboko wierzący - 6,1\%, wierzący - 9,6\%, niezdecydowani w sprawach wiary, ale przywiązani do tradycji - 12,3\%, obojętni w sprawach religijnych $15,8 \%$, niewierzący - 19,9\%. Skrajne stanowiska dzieli przedział 13,8\%. Także wraz ze zmniejszaniem się praktyk religijnych wzrasta procent młodzieży ceniącej omawianą wartość: praktykujący raz w tygodniu i częściej - 9,5\%, od 1 do 3 razy w miesiącu - 10,2\%, kilka razy w roku 13,7\%, niepraktykujący $-16,1 \%$. W tym przypadku wielkości graniczne dzieli 6,6\%.

\section{Silny charakter}

W przypadku korelacji religijności z silnym charakterem zaobserwowano następującą tendencję: im bardziej zmniejsza się religijność, tym wzrasta odsetek młodzieży ceniącej silny charakter jako dobro. W przypadku identyfikacji $\mathrm{z}$ wiarą rozkład procentowy odpowiedzi przedstawia się następująco: głęboko wierzący $-5,3 \%$, wierzący $-11,6 \%$, niezdecydowani w sprawach wiary, ale przywiązani do tradycji - 15,8\%, obojętni w sprawach religijnych $-18,0 \%$, niewierzący $-20,6 \%$. Natomiast zestawiając praktyki religijne $\mathrm{z}$ silnym charakterem, wielkości przybrały następujące walory: praktykujący raz w tygodniu i częściej - 10,1\%, od 1 do 3 razy w miesiącu - 12,4\%, kilka razy w roku 15,2\%, niepraktykujący - 20,3\%. Taki rozkład wyników można tłumaczyć faktem, że osoby o słabszej religijności w większym stopniu opierają się na sobie i mają przekonanie o własnej sprawczości niż osoby o silniejszej wierze w rzeczywistość pozaempiryczną. Te pozostawiają w swym życiu miejsce na działanie sił nadprzyrodzonych. 


\section{Kariera zawodowa}

Gdy identyfikacja z wiarą słabnie, rośnie odsetek uczniów ceniących karierę zawodową: głęboko wierzący - 19,2\%, wierzący - 27,3\%, niezdecydowani w sprawach wiary, ale przywiązani do tradycji $-29,6 \%$, obojętni w sprawach religijnych $-30,7 \%$, niewierzący - 32,3\%. W uzyskany trend wpisuje się także zestawienie, w którym wzięto pod uwagę zmienną niezależną praktyki religijne. W tym przypadku otrzymano następujący ciąg wielkości: praktykujący raz w tygodniu i częściej - 24,7\%, od 1 do 3 razy w miesiącu - 29,0\%, kilka razy w roku 29,5\%, niepraktykujący - 31,6\%. Wielkości graniczne dzieli 6,9\%. „Robienie kariery zawodowej pociąga za sobą zwiększanie profitów finansowych. Zatem tę wartość można kojarzyć z czynnikiem materialnym. Dla wierzących (pozostających w kręgu wartości idealnych) wyżej wskazane dobro ma mniejszą atrakcyjność niż dla osób o ograniczonej wrażliwości na to, co pozostaje poza zmysłami.

\section{Zdobywanie wiedzy}

Z małymi wyjątkami zauważa się także tendencję świadczącą, że wraz ze słabnięciem religijności zwiększa się odsetek uczniów ceniących wiedzę. Jest tak w przypadku obu uwzględnianych parametrów religijności. Korelując identyfikację z wiarą z tą zmienną, otrzymaliśmy następujące zestawienie wyników: głęboko wierzący $-7,8 \%$, wierzący $-6,7 \%$, niezdecydowani w sprawach wiary, ale przywiązani do tradycji - 9,5\%, obojętni w sprawach religijnych $-9,9 \%$, niewierzący $-13,6 \%$. Natomiast w przypadku praktyk religijnych wyniki układały się następująco: praktykujący raz w tygodniu i częściej - 8,0\%, od 1 do 3 razy w miesiącu $-7,0 \%$, kilka razy w roku 8,5\%, niepraktykujący - 11,2\%.

\section{Szczęśliwe życie rodzinne}

Kolejną wartością, której korelacja z religijnością budowała jednoznaczną zależność, było szczęśliwe życie rodzinne. $\mathrm{W}$ tym zestawieniu zanotowano następujący związek: wraz ze słabnięciem identyfikacji z wiarą zmniejsza się odsetek uczniów ceniący szczęśliwe życie rodzinne: głęboko wierzący - 63,9\%, wierzący $64,0 \%$, niezdecydowani w sprawach wiary, ale przywiązani do tradycji $-56,9 \%$, obojętni w sprawach religijnych - 47,2\%, niewierzący - 34,7\%. Różnica między skrajnymi wielkościami wyniosła blisko 30 punktów procentowych. Kolejny wskaźnik potwierdza także tę prawidłowość - wraz ze słabnięciem religijności zwiększa się dystans badanych do rozpatrywanej wartości. Praktykujący raz 
w tygodniu i częściej - 62,9\%, od 1 do 3 razy w miesiącu - 61,4\%, kilka razy w roku $57,2 \%$, niepraktykujący - 40,4\%. Skrajne wielkości dzieli przedział ponad 20 punktów procentowych.

Pomaganie innym ludziom

W przypadku altruizmu otrzymaliśmy także wyraźne zależności - przy rosnącej identyfikacji z wiarą zwiększa się odsetek uczniów ceniących wskazaną wartość: głęboko wierzący - 17,7\%, wierzący - 11,3\%, niezdecydowani $\mathrm{w}$ sprawach wiary, ale przywiązani do tradycji $-10,5 \%$, obojętni w sprawach religijnych $-9,5 \%$, niewierzący $-8,5 \%$.

Tę relację, z małym wyjątkiem, potwierdza zestawienie omawianej wartości z praktykami religijnymi: praktykujący raz w tygodniu i częściej - 13,0\%, od 1 do 3 razy w miesiącu $-9,4 \%$, kilka razy w roku 10,4\%, niepraktykujący - 10,3\%.

\section{Dobro ojczyzny}

Uwzględniając dwa wymiary religijności, możemy stwierdzić, że istnieje prawidłowość świadcząca, że wraz ze zwiększaniem się religijności rośnie odsetek uczniów ceniących dobro ojczyzny. Przy zmiennej niezależnej „identyfikacja z wiarą" otrzymaliśmy następujący układ wielkości: głęboko wierzący - 11,1\%, wierzący $-5,4 \%$, niezdecydowani w sprawach wiary, ale przywiązani do tradycji $3,4 \%$, obojętni w sprawach religijnych $-2,3 \%$, niewierzący $-2,7 \%$. Natomiast przy zmiennej niezależnej praktyki religijne wyniki układały się w porządku: praktykujący raz w tygodniu i częściej - 7,0\%, od 1 do 3 razy w miesiącu $-4,9 \%$, kilka razy w roku $2,9 \%$, niepraktykujący $-2,8 \%$.

\section{$* * *$}

Podsumowując zestawienie religijności z dobrami uznanymi za ważne w życiu respondentów, można sformułować następujące uwagi:

- wraz ze słabnięciem religijności wzrasta wśród uczniów uznanie dla wartości materialno-hedonistycznych (pieniądze i zamożność, przyjemność i rozrywka) oraz wartości pozwalających własnymi siłami pokonywać wyzwania i trudności życiowe (silny charakter, zdobywanie wiedzy, kariera zawodowa);

- wraz ze wzrostem religijności wzrasta uznanie dla dóbr związanych z wartościami podkreślającymi walory wspólnotowości (szczęśliwe życie rodzinne, dobro ojczyzny) oraz altruistycznymi (pomaganie innym ludziom). 


\section{Religijność a stosunek uczniów do wybranych norm obyczajowych}

Normy są podstawowym atrybutem życia zbiorowego. Najkrócej daje się je zdefiniować jako zestandaryzowany sposób działania jednostek lub grup społecznych uznany za pożądany i oczekiwany w określonym kontekście kulturowym ${ }^{31}$. W obiegu potocznym norma często jest określana jako zwyczaj, obyczaj, moda, tradycja, konwencja, prawo, reguła. Normy jako regulatory zachowań uściślają wartości; są ich uszczegółowieniem w kontekście konkretnych faktów społecznych. Przenoszą myślenie z ogólnej formuły, np. „własność jest wartością,, na wymiar jednoznacznego zalecenia - „nie wolno zawłaszczać cudzego mienia”32. W zależności od obszarów faktów, do jakich odnoszą się regulacje, można mówić o różnych typach norm. Maria Ossowska wymieniła wśród nich następujące, służące: obronie jednostkowego istnienia człowieka, godności, wolności, umacnianiu zaufania, sprawiedliwości, harmonijnego współżycia grupowego, rozładowujące konflikty społeczne ${ }^{33}$. Można także zastosować bardziej ogólny podział norm na: moralne, obyczajowe, prawne, religijne. Jak głosi tytuł paragrafu, w tym fragmencie tekstu zajmiemy się stosunkiem uczniów do norm obyczajowych. To znaczy, że będziemy odnosić się do zachowań uchodzących w konkretnej zbiorowości za akceptowane i przypieczętowane tradycją. Zakres takich zachowań jest bardzo szeroki ${ }^{34}$. W prezentowanym opracowaniu ograniczymy się jedynie do następujących kwestii: współżycia seksualnego przed ślubem, stosowania środków antykoncepcyjnych, przerywania ciąży oraz niewierności małżeńskiej. Oczywiście opinie uczniów na te kwestie będą korelowane z ich religijnością.

\section{Współżycie seksualne przed ślubem}

W przypadku zmiennej niezależnej „identyfikacja z wiarą” nie było odstępstwa od jednoznacznej reguły: wraz ze słabnięciem identyfikacji z wiarą spada odsetek uczniów negatywnie nastawionych do zjawiska: głęboko wierzący - 52,4\%, wierzący $-22,7 \%$, niezdecydowani w sprawach wiary, ale przywiązani do tradycji - 11,3\%, obojętni w sprawach religijnych - 8,7\%, niewierzący - 8,0\%. Różnica między skrajnymi stanowiskami jest ponad sześciokrotna. Uwzględniając udział respondentów w praktykach religijnych, w kontekście ich stosunku do współżycia seksualnego przed ślubem także zauważamy prawidłowość ( $z$ niewielkim odstępstwem u niepraktykujących), zgodnie z którą wraz ze słabnięciem zaangażowania

${ }^{31}$ M. Zemło, Młodzież na rozstajach. Aksjonormatywne orientacje uczniów szkół ponadpodstawowych, Wydawnictwo Uniwersytetu w Białymstoku, Białystok 2019, s. 43.

32 J. Mariański, Socjologia moralności, Wydawnictwo KUL, Lublin 2006, s. 301-302.

33 M. Ossowska, Normy moralne. Próba systematyzacji, PWN, Warszawa 1985.

34 M. Zemło, Młodzież na rozstajach..., s. 50-51. 
się w praktyki zmniejsza się odsetek uczniów negatywnie ustosunkowanych do braku wstrzemięźliwości seksualnej przed ślubem. Następujące zestawienie precyzuje wskazaną zależność: praktykujący raz w tygodniu i częściej - 30,8\%, od 1 do 3 razy w miesiącu - 16,3\%, kilka razy w roku 10,9\%, niepraktykujący 11,1\%. Różnica między skrajnymi stanowiskami jest trzykrotna.

\section{Stosowanie środków antykoncepcyjnych}

Biorąc pod uwagę identyfikację z wiarą i opinię na temat stosowania środków antykoncepcyjnych, zauważa się prawidłowość wyrażoną w zdaniu: wraz ze słabnięciem owej identyfikacji maleje odsetek osób krytycznie odnoszących się do omawianego zjawiska: głęboko wierzący - 43,8\%, wierzący - 21,8\%, niezdecydowani w sprawach wiary, ale przywiązani do tradycji - 11,1\%, obojętni w sprawach religijnych $-10,7 \%$, niewierzący $-8,8 \%$. Między skrajnymi stanowiskami wystąpiła czterokrotna różnica. Uwzględniając zmienną niezależną - udział w praktykach religijnych oraz stosunek do stosowania środków antykoncepcyjnych - zauważa się prawidłowość świadczącą, że także i w tym przypadku wraz ze słabnięciem praktykowania zmniejsza się odsetek negatywnie oceniających omawiane zjawisko: praktykujący raz w tygodniu i częściej - 27,9\%, od 1 do 3 razy w miesiącu $-15,7 \%$, kilka razy w roku $12,2 \%$, niepraktykujący $-11,2 \%$.

\section{Przerywanie ciąży}

Kolejna kwestia dotyczyła przerywania ciąży. W tym przypadku zanotowano wyraźną prawidłowość między autodeklaracją wiary a stosunkiem do aborcji. Wraz ze słabnięciem identyfikacji z wiarą drastycznie spada liczba negatywnie nastawionych do przerywania ciąży: głęboko wierzący - 78,5\%, wierzący - 61,8\%, niezdecydowani w sprawach wiary, ale przywiązani do tradycji - 41,2\%, obojętni w sprawach religijnych - 29,9\%, niewierzący - 17,5\%. Skrajne wielkości dzieli 60 punktów procentowych. Biorąc pod uwagę zmienną niezależną praktyki religijne i negatywną ocenę przerywania ciąży, zauważamy prawidłowość, zgodnie z którą wraz ze słabnięciem przywiązania do praktyk religijnych zmniejsza się odsetek młodzieży negatywnie nastawionych do omawianej praktyki. Zależność tę wyraża następujący ciąg danych: praktykujący raz w tygodniu i częściej - 65,3\%, od 1 do 3 razy w miesiącu $-49,4 \%$, kilka razy w roku 40,8\%, niepraktykujący $-27,4 \%$. W tym przypadku różnica między skrajnymi grupami wyniosła 50 punktów procentowych. Przyglądając się uzyskanym danym, śmiało można powiedzieć, że głęboko wierzący oraz praktykujący raz w tygodniu i częściej przynależą do zupełnie innej konstelacji aksjonormatywnej niż niewierzący i niepraktykujący. 


\section{Niewierność małżeńska}

W przypadku korelacji religijności z opinią na temat niewierności małżeńskiej także zanotowano niezakłóconą zależność wyrażaną w stwierdzeniu: wraz ze słabnięciem identyfikacji z wiarą zmniejsza się odsetek osób negatywnie oceniających badane zjawisko: głęboko wierzący - 86,1\%, wierzący - 82,1\%, niezdecydowani w sprawach wiary, ale przywiązani do tradycji - 81,9\%, obojętni w sprawach religijnych - 72,8\%, niewierzący - 72,5\%. Dysproporcje między poszczególnymi kategoriami uczniów nie były tak wyraźne jak w przypadku poprzednich norm. Częstotliwość praktyk religijnych w zestawieniu z niewiernością małżeńską także pozwalało zauważyć jednoznaczne zależności. Podobnie jak w poprzednich przypadkach obserwuje się tendencję, zgodnie z którą wraz ze słabnięciem praktyk religijnych zmniejsza się odsetek uczniów negatywnie oceniających zjawisko niewierności małżeńskiej. Wspomniana prawidłowość pokazuje następujący ciąg wielkości: praktykujący raz w tygodniu i częściej - 84,2\%, od 1 do 3 razy w miesiącu - 81,0\%, kilka razy w roku 77,6\%, niepraktykujący - 73,5\%.

$$
* * *
$$

Na podsumowanie niniejszego punktu artykułu wskażemy zasadnicze tendencje odnoszące się do treści w nim zawartych:

- w zestawieniu wszystkich przebadanych norm obyczajowych z religijnością zauważa się prawidłowość, zgodnie z którą im osoby mniej religijne (w obu rozpatrywanych wymiarach religijności), tym w większym stopniu je akceptują ${ }^{35}$

- największe dysproporcje między skrajnymi stanowiskami uczniów wystąpiły w kwestii przerywania ciąży. Różnica, jaką zaobserwowano między skrajnymi stanowiskami pozwala wnosić, że grupy podzielające skrajne poglądy przynależą do odmiennych światów aksjologicznych. Uzyskane dane upoważniają do stwierdzenia, iż jest to obszar faktów, pozostający pod bardzo mocnym wpływem czynnika religijnego;

- największą zgodność między skrajnymi stanowiskami notuje się w sytuacji niewierności małżeńskiej - 10,7\%. Z tego faktu możemy wnioskować, że w tym przypadku zauważa się stosunkowo niewielki wpływ czynnika religijnego na poglądy respondentów.

35 Por. J. Baniak, Kryzys tożsamości a świadomość moralna młodzieży gimnazjalnej. Studium socjologiczne, w: Wartości postawy i więzi moralne w zmieniającym się społeczeństwie, red. J. Mariański, L. Smyczek, Wydawnictwo WAM, Polskie Towarzystwo Socjologiczne, Kraków 2008, s. 172; J. Mariański, Kondycja religijna i moralna młodzieży szkół średnich w latach 1988-1998-2005-2017..., s. 231. 


\section{Religijność a stosunek uczniów do zachowań ryzykownych}

Religijność, jako odpowiednio ukształtowany system aksjonormatywny, ma moc oddziaływania na wiele spraw w życiu człowieka. Może m.in. wykazywać się aktywnością w: wyznaczaniu sposobu rozwiązywania napotkanych trudności, określaniu kierunku podejmowanym działaniom, dobieraniu strategii $\mathrm{w}$ ich realizacji, dobieraniu obszarów zainteresowań, angażowaniu się w wybrane przedsięwzięcia, określaniu relacji względem innych i względem siebie samego ${ }^{36}$. W niniejszym fragmencie tekstu starano się znaleźć odpowiedź na pytanie, czy religijność ma związek ze stosunkiem młodzieży szkolnej do zachowań ryzykownych? Poniżej zestawiono zmienną niezależną z następującymi działaniami o charakterze ryzykownym: palenie papierosów, picie alkoholu, upijanie się alkoholem, używania środków odurzających.

\section{Palenie papierosów}

W przypadku stosunku do wiary zauważa się jednoznaczną tendencję: wraz ze słabnięciem identyfikacji z wiarą spadał odsetek uczniów negatywnie wypowiadających się o paleniu papierosów. Wyniki układały się następująco: głęboko wierzący - 71,9\%, wierzący - 56,2\%, niezdecydowani w sprawach wiary, ale przywiązani do tradycji - 46,0\%, obojętni w sprawach religijnych $36,0 \%$, niewierzący $-33,0 \%$. Natomiast biorąc pod uwagę udział w praktykach religijnych, zauważa się także niezakłóconą zależność: wraz ze spadkiem udziału w praktykach religijnych zmniejsza się odsetek respondentów negatywnie wypowiadających się o paleniu papierosów: praktykujący raz w tygodniu i częściej - 61,7\%, od 1 do 3 razy w miesiącu - 48,9\%, kilka razy w roku 42,6\%, niepraktykujący $-36,7 \%$.

\section{Picie alkoholu}

Także w przypadku picia alkoholu zanotowano niezakłóconą prawidłowość w ocenie zjawiska, gdy skorelowało się ją ze stosunkiem do wiary respondentów. Gdy identyfikacja z wiarą malała, zmniejszał się odsetek uczniów mających negatywne zdanie o piciu trunków procentowych: głęboko wierzący - 67,1\%, wierzący - 41,9\%, niezdecydowani w sprawach wiary, ale przywiązani do tradycji $-40,0 \%$, obojętni w sprawach religijnych $-31,9 \%$, niewierzący - 27,7\%. Różnica między skrajnymi stanowiskami wyniosła 40

\footnotetext{
${ }^{36}$ J. Szymczyk, Wokół wartości i więzi społecznych Polaków..., s. 6.
} 
punktów procentowych. W tym przypadku możemy mówić, że mentalnie reprezentanci tych grup żyją w dwóch odmiennych światach. Deklaracja udziału w praktykach religijnych $\mathrm{w}$ zestawieniu z oceną picia alkoholu przez młodzież także pozwalała na zauważenie jednoznacznej relacji. Wraz ze zmniejszaniem się udziału w praktykach religijnych malał odsetek uczniów negatywnie oceniających badane zjawisko. Rozkład wyników był następujący: praktykujący raz w tygodniu i częściej - 57,0\%, od 1 do 3 razy w miesiącu $46,0 \%$, kilka razy w roku 37,8\%, niepraktykujący - 30,6\%. Przy tym wskaźniku religijności już nie było tak dużych dysproporcji między skrajnymi grupami jak przy poprzednim wymiarze wiary, niemniej dzielił ich przedział ponad 25 punktów procentowych.

\section{Upijanie się alkoholem}

Upijanie się alkoholem jest ekstremalną formą kontaktu z trunkami wysokoprocentowymi. Stąd można podejrzewać, że prawidłowości zanotowane w poprzednim punkcie powtórzą się w związku z tym zachowaniem. Uzyskane wyniki potwierdzają takie przypuszczenia. Notuje się bowiem jednoznaczną prawidłowość świadczącą o tym, że wraz ze zwiększaniem się religijności maleje akceptacja nadmiernego spożywania alkoholu. W przypadku identyfikacji z wiarą otrzymano następujące zestawienie: głęboko wierzący - 79,0\%, wierzący $70,0 \%$, niezdecydowani w sprawach wiary, ale przywiązani do tradycji $-62,6 \%$, obojętni w sprawach religijnych $-50,0 \%$, niewierzący $-46,8 \%$. Natomiast przy uwzględnieniu praktyk religijnych wyniki układały się w ciągu: praktykujący raz w tygodniu i częściej - 73,8\%, od 1 do 3 razy w miesiącu - 65,4\%, kilka razy w roku $58,9 \%$, niepraktykujący $-48,5 \%$.

\section{Używanie środków odurzających}

W opinii społecznej używanie środków odurzających jest najmniej akceptowane ze wszystkich wcześniej omówionych zachowań ryzykownych. Także i w kontekście takiej praktyki stwierdzono niezakłóconą prawidłowość świadczącą, że wraz ze słabnięciem identyfikacji z wiarą spadał odsetek uczniów negatywnie wypowiadających się o referowanym zachowaniu ryzykownym: głęboko wierzący - 81,8\%, wierzący - 76,4\%, niezdecydowani w sprawach wiary, ale przywiązani do tradycji - 69,7\%, obojętni w sprawach religijnych $-57,3 \%$, niewierzący - 50,0\%. Różnica między skrajnymi grupami wyniosła ponad 30 punktów procentowych. Zestawiając deklaracje udziału w praktykach religijnych z negatywną oceną używania środków odurzających przez młodzież, potwier- 
dzono tę zależność, tj. wraz ze słabnięciem częstotliwości praktyk zmniejsza się odsetek badanych negatywnie wyrażających się o używaniu środków odurzających. Wyraża to następujący ciąg danych: praktykujący raz w tygodniu i częściej - 78,3\%, od 1 do 3 razy w miesiącu - 71,1\%, kilka razy w roku 69,1\%, niepraktykujący - 53,0\%. Między grupami sytuującymi się biegunowo pojawiła się różnica 25 punktów procentowych.

$$
* * *
$$

W przypadku każdego z badanych zachowań ryzykownych zanotowano niezakłóconą prawidłowość wyrażoną w sentencji: wraz ze zwiększaniem się religijności następuje wzrost negatywnego nastawienia do aktywności zagrażających zdrowiu człowieka. Dotyczy to obu wymiarów religijności w każdej z omawianych kwestii. Należy zauważyć tutaj jeszcze jedną zależność: w każdym z przypadków stwierdzono większe różnice w ocenie zachowań ryzykownych między skrajnymi grupami respondentów, biorąc pod uwagę wymiar identyfikacji z wiarą niż wymiar praktyk religijnych.

\section{Zakończenie}

Człowiek żyjący w dzisiejszych czasach charakteryzujących się dużym dynamizmem ma kłopoty z nadążaniem za zachodzącymi zmianami. Nie potrafi odnaleźć się w całym zestawie technicznej infrastruktury, która co kilka lat zaskakuje kolejnymi nowinkami; nie zawsze rozumie, co się dzieje w kulturze, w której nowe kanony piękna wyparły klasyczne i uzurpują sobie bycie - choćby na chwilę - latarnią rzucającą światło wskazujące cenione standardy dla twórców; dziwi się, spoglądając na sposoby spędzania czasu wolnego; nie pojmuje, dlaczego takie, a nie inne formy przybierają relację młodego pokolenia do pokolenia rodziców i dziadków; wchodzi w osłupienie, gdy zderza się ze współczesnymi modelami życia obyczajowego itd. Szczególnie nie radzą sobie z tymi przemianami ci, którzy byli przyzwyczajeni do innego oblicza świata niż aktualnie istniejący. Człowiek pamiętający odleglejsze czasy ma większe kłopoty $\mathrm{z}$ odnalezieniem się we współcześnie obowiązujących standardach. Pomocne w tym są próby dotarcia do aksjologii leżącej u podstaw ludzkich działań. Jeśli uda się zidentyfikować jej elementy, może nastąpić przełamanie wycofanego nastawienia do świata. Jak mówił J. Szymczyk, nasza wiedza nie będzie już wówczas powierzchowna, pobieżna, uboga, ale będziemy mogli zejść nieco głębiej, pod powłokę behawioralnej formy, w której człowiek wyraża swoje ekspresje. Wówczas otworzy się sposobności rozumienia relacji społecznych, schematów 
działań, wzorów zachowań, stylów życia, mentalności, tożsamości, hierarchii społecznych, systemów politycznych, ruchów społecznych itd. ${ }^{37}$

$\mathrm{W}$ prezentowanym materiale staraliśmy się odsłonić kilka aspektów związanych z systemem aksjologicznym współczesnej młodzieży szkolnej. Pokazaliśmy stan jej religijności (opierając się na autodeklaracjach wiary i praktykach religijnych) oraz najbardziej cenione przez nią dobra, a także jej nastawienie do wybranych wartości, norm i zachowań z uwzględnieniem religijności jako zmiennej niezależnej. Coraz częściej, także w kontekście polskim, mówi się o słabnięciu znaczenia religii w życiu społeczeństw. Przy tej okazji głosi się diagnozy wyrażane $\mathrm{w}$ następujących określeniach: emigracja z Kościoła, odkościelnienie, zmierzch Kościoła, zanikanie religii, kryzys religii, upadek religii, koniec religii, kryzys Boga, śmierć Boga ${ }^{38}$. Szczególnie takie opinie dotyczą młodego pokolenia, które nie ma wystarczających kompetencji oraz umacniających w wierze doświadczeń, by przeciwstawiać się naporowi laickich wartości i modelom życia lansowanym przez modernistyczne trendy, silną falą uderzających z Zachodu. Zwracają na to uwagę liczni socjologowie ${ }^{39}$. Kolejne ekspertyzy mogą umacniać przekonanie, że aktualnie religia już nie przynależy do spraw ważnych, że jej wpływ na życie traci na znaczeniu, a właściwie już może zupełnie nie oddziałuje na współczesnych ${ }^{40}$. W przedłożonym w niniejszym opracowaniu materiale pokazaliśmy, miejscami nadzwyczaj wyraźnie, że tego typu przypuszczenia są nazbyt śmiałe i przedwczesne. Być może to, co dostrzegamy zmysłami (zarzucanie praktyk religijnych, bunt przeciw Kościołowi zinstytucjonalizowanemu, eksponowanie wrogości względem religii itp.), niekoniecznie pokazuje całą prawdę o religijności młodzieży. Religijność w swej naturze jest stanem ducha i sięgając do tej płaszczyzny, można wystawić jej bardziej trafną diagnozę. Oczywiście socjologowi bezpośrednie dotarcie do tych rewirów jest niedostępne. Jednak niekiedy można dokonać głębszego wglądu w badany fenomen w sposób pośredni. W niniejszym opracowaniu, odwołując

${ }_{37}$ Tenże, Odkrywanie wartości..., s. 252-253; tenże, Wokół wartości i więzi społecznych Polaków..., s. $5-6,21$.

38 J. Mariański, Scenariusze przemian religijności i Kościoła katolickiego w społeczeństwie polskim..., s. $16-17,28,38,41-42$.

${ }^{39}$ S.H. Zaręba, Socjologiczne interpretacje moralnych poglądów i ocen polskiej młodzieży szkolnej i akademickiej..., s. 231-232; T. Adamczyk, Postawy moralne studentów w warunkach zmiany społecznej, w: Wartości postawy i więzi moralne..., s. 237-238, 250, 253; S.H. Zaręba, Horyzonty moralności polskiego ucznia i studenta, w: Moralne dylematy Polaków w ponowoczesności. Wybrane problemy, red. A. Maksymowicz, Zakład Wydawniczy Nomos, Kraków 2009, s. 205-220; I. Borowik, Przemiany religijne w Polsce na tle transformacji w Europie Srodkowo-Wschodniej i globalizacji, w: Globalny i lokalny wymiar religii. Polska w kontekście Europejskim, red. I. Borowik, A. Górny, W. Świątkiewicz, Zakład Wydawniczy Nomos, Kraków 2016, s. 7-16.

${ }^{40}$ Por. J. Mariański, Kondycja religijna i moralna młodzieży szkót średnich w latach 1988-19982005-2017..., s. 11. 
się do opinii badanych dotyczących fundamentalnych, a także drugoplanowych kwestii związanych z moralnością, poczyniliśmy taką próbę, która może w pewnym zakresie satysfakcjonować. Uzyskane efekty pracy badawczej dowodzą, że religia wciąż żywo odciska swoje piętno, nawet na najmłodszym pokoleniu. Tym samym dokonana diagnoza wychodzi $\mathrm{z}$ alternatywną interpretacją kondycji religijności w porównaniu z większością opracowań i ekspertyz.

\section{Bibliografia}

Adamczyk T., Postawy moralne studentów w warunkach zmiany społecznej, w: Wartości postawy i więzi moralne w zmieniającym się społeczeństwie, red. J. Mariański, L. Smyczek, Wydawnictwo WAM, Polskie Towarzystwo Socjologiczne, Kraków 2008, s. 235-265.

Baniak J., Kryzys tożsamości a świadomość moralna młodzieży gimnazjalnej. Studium socjologiczne, w: Wartości postawy i więzi moralne w zmieniającym się społeczeństwie, red. J. Mariański, L. Smyczek, Wydawnictwo WAM, Polskie Towarzystwo Socjologiczne, Kraków 2008, s. $163-204$.

Borowik I., Przemiany religijne w Polsce na tle transformacji w Europie Środkowo-Wschodniej i globalizacji, w: Globalny i lokalny wymiar religii. Polska w kontekście Europejskim, red. I. Borowik, A. Górny, W. Świątkiewicz, Zakład Wydawniczy Nomos, Kraków 2016, s. 7-16.

Jakość życia i kapitał społeczny w Polsce. Wyniki badań spójności społecznej 2018, GUS, Warszawa 2020, s. 111-112.

Mariański J., Socjologia moralności, Wydawnictwo KUL, Lublin 2006.

Mariański J., Kondycja religijna i moralna młodzieży szkół średnich w latach 1988-1998-2005-2017 (raport z ogólnopolskich badań socjologicznych), Wydawnictwo Adam Marszałek, Toruń 2018.

Mariański J., Maturzyści puławscy w latach 1994-2016. Szkic do portretu młodych Polaków, Warszawskie Wydawnictwo Socjologiczne, Warszawa 2019.

Mariański J., Religijnosocjologiczne wyzwania dla pedagogiki religii. Studium socjologiczne, Wydawnictwo Adam Marszałek, Toruń 2021.

Mariański J., Scenariusze przemian religijności i Kościoła katolickiego w społeczeństwie polskim. Studium diagnostyczno-prognostyczne, Wyższa Szkoła Nauk Społecznych z siedzibą w Lublinie, Lublin 2021.

Ossowska M., Normy moralne. Próba systematyzacji, PWN, Warszawa 1985.

Styl życia młodzieży Białegostoku, red. J. Mantur, Centrum Kształcenia Ustawicznego w Białymstoku, Białystok 2019.

Szczepański J., Elementarne pojęcia socjologii, PWN, Warszawa 1970.

Szymczyk J., Instytucje, procesy i systemy społeczne. Makrosocjologia, w: 100 lat socjologii w Katolickim Uniwersytecie Lubelskim Jana Pawła II. Idee - Teorie - badania, red. W. Szymczak, TN KUL, Lublin 2018, s. 63-85.

Szymczyk J., Katedra socjologii makrostruktur i ruchów Społecznych, w: Tradycja i współczesność. 90 lat socjologii w katolickim Uniwersytecie Lubelskim, red. S. Fel, J.P. Gałkowski, J.M. Zabielska, Wydawnictwo KUL, Lublin 2009, s. 147-150.

Szymczyk J., Odkrywanie wartości. Z problematyki socjologiczno-aksjologicznej, Polihymnia, Lublin 2004.

Szymczyk J., Przemiany wartości i więzi we współczesnym społeczeństwie polskim, w: Odpowiedzialność społeczna w innowacyjnej gospodarce, red. P. Kowalec, A. Blachuta, Wydawnictwo KUL, Lublin 2011, s. 299-319.

Szymczyk J., Wartości a zachowania i działania społeczne, w: Segmenty aktywności społecznej a wartości. Idee i praktyka, red. J. Szymczyk, Wydawnictwo KUL, Lublin 2012, s. 9-35. 
Szymczyk J., Wokół wartości i więzi społecznych Polaków. Wybrane aspekty i tendencje , „Zeszyty Naukowe KUL" 2010, t. 53, nr 4, s. 3-22.

Szymczyk J., Zamiast wprowadzenia. O Katedrze Socjologii Makrostruktur i Ruchów Społecznych, w: Wartości - interesy - struktury społeczne. Uwarunkowania ludzkiej kreatywności i partycypacji w życiu publicznym, red. J. Szymczyk, Norbertinum, Lublin 2010, s. 5-15.

Zaręba S.H., Socjologiczne interpretacje moralnych poglądów i ocen polskiej młodzieży szkolnej i akademickiej, w: Wartości postawy i więzi moralne w zmieniającym się społeczeństwie, red. J. Mariański, L. Smyczek, Wydawnictwo WAM, Polskie Towarzystwo Socjologiczne, Kraków 2008, s. 205-233.

Zaręba S.H., Horyzonty moralności polskiego ucznia i studenta, w: Moralne dylematy Polaków w ponowoczesności. Wybrane problemy, red. A. Maksymowicz, Zakład Wydawniczy Nomos, Kraków 2009, s. 205-220.

Zemło M., Między szkołą a domem. Konteksty socjalizacyjne młodzieży szkół ponadpodstawowych, Wydawnictwo KUL, Lublin 2013.

Zemło M., Młodzież na rozstajach. Aksjonormatywne orientacje uczniów szkółponadpodstawowych, Wydawnictwo Uniwersytetu w Białymstoku, Białystok 2019.

\section{Streszczenie}

W niniejszym tekście opierając się na badaniach empirycznych, dokonano zidentyfikowania religijności młodzieży uczęszczającej do placówek edukacyjnych na terenie Białegostoku. W pierwszej kolejności przedstawiono jej obraz, posługując się dwoma wskaźnikami: autodeklaracją wiary i praktykami religijnymi. Zdając sobie sprawę, że takie podejście nie identyfikuje w pełni badanego fenomenu, w dalszej części tekstu postanowiono zestawić oba wskaźniki religijności z: wartościami najbardziej cenionymi przez badanych, ich opiniami na temat wybranych norm obyczajowych oraz poglądami odnoszącymi się do najczęściej praktykowanych przez uczniów zachowań ryzykownych. Dopełnienie obrazu religijności przez takie uzupełnienie pozwoli z większą wnikliwością ocenić kondycję religijności pokolenia stojącego na progu dorosłości oraz wyrobić zdanie na temat ich systemu aksjologicznego.

Słowa kluczowe: religijność, system wartości, normy moralne, młodzież szkolna

\section{Religiousness of Students in Białystok Schools and Their Attitude to Selected Values, Norms and Behaviours}

\section{Summary}

This text uses empirical research to investigate the religiosity of youth attending educational institutions in Białystok. First, we discuss how religiousness is perceived by our respondents. In drawing this general picture, we relied on two indicators: self-declaration of faith and declared religious practices. Keeping in mind that researching these two issues cannot yield an exhaustive diagnosis of youth religiousness, in the latter part of the text the authors juxtapose the two parameters mentioned above against the information collected from the respondents on the values that they appreciate the most, their opinions on selected moral norms and their views on the most frequently practiced risk behaviors. Complementing the primary picture and perception of religiosity with the information from the supplementary questions allows for a more insightful assessment of the status of religiosity in the studied pre-adult generation, also enabling a reflection on their axiological systems.

Key words: religiosity, value system, moral norms, school students 